Relevance of Gandhian Thoughts about Sanitation and Related Policies of Government: ............... Dr. Anchal Gupta

\title{
Relevance of Gandhian Thoughts about Sanitation and Related Policies of Government: A Sociological Perspective
}

\author{
Dr. Anchal Gupta, \\ Associate Professor, Dept. of Sociology, \\ GDHG College, Moradabad \\ Email: anchalgupta.gdhg@gmail.com
}

\begin{abstract}
Sanitation is the hygienic means of promoting health through prevention of human contact with the hazards of wastes as well as the treatment and proper disposal of sewage or wastewater. As we know that sanitation is most important in our daily life as well as for the nation. It is our basic and essential need. It is also very well known that our father nation, Mahatma Gandhi personally took an effort to achieve the change that he wanted to see. We found the clear concept of sanitation from the writings of great people like Vivekananda and Mahatma Gandhi. They all emphasize on cleanliness which is an integral part of India's cultural foundation. After so many decades their thoughts and writings are most relevant, meaningful, and useful for the present society.
\end{abstract}

Reference to this paper should be made as follows:

Received: 15.8 .2020

Approved: 30.09.2020

Dr. Anchal Gupta,

Relevance of Gandhian Thoughts about Sanitation and Related Policies of Government: A Sociological Perspective

Article No. 29

RJPSS Sept. 2020,

Vol. XLV No. 2,

pp. 246-250

Online available at:

https://anubooks.com/

rjpss-2020-vol-xlv-no-2/

https://doi.org/10.31995/

rjpss.2020.v45i01.026 
RJPSS Sept. 2020 Vol. XLV No.2, ISSN: (P)0258-1701 (e)2454-3403 Impact Factor: 7.717

https://doi.org/10.31995/rjpss.2020.v45i01.026

\section{Introduction:}

As we know through the Indian history the Indian caste system is a unique method of social stratification. It divides the society into four parts but basically in two as high caste and low caste. This fact is also very interesting to know that only birth decides that who is placed in higher or in the lower cast in the hierarchy system. Gandhi Ji always opposed the caste system because it is the main source of increasing discrimination in the society. Although many reformations have been made by the social reformers and the government regarding this system but still many of them could not be benefitted.

\section{Gandhian Ideology about Sanitation :}

Mahatma Gandhi always said that everyone must be his own scavenger. As we know that we gained freedom under the leadership of Gandhi Ji, but it is very sad that till today we are unable to fulfill his dream of clean India. Gandhi Ji said that sanitation is more important than independence. The thoughts of Gandhi Ji are more relevant in the present time. His dream was total sanitation for all. Everyone needs to learn about personal hygiene and cleanliness as certain habits like washing hands before every meal, regular brushing teeth, bathing daily, and wear clean cloth, etc. He said, "I will not let any more walk through my mind with their dirty feet." They never bothered and hesitate to clean the toilet and public place also.

Gandhi Ji's family belongs to Rajkot, his father was a Deewan in Rajkot. A Mehtar (sweeper) did scavenging in their house, Gandhi Ji was strictly instructed by the family not to touch him and if he touched him, his mother made him take a bath. Although, he was an obedient son but he argued on this matter.

Mahatma Gandhi always said we should learn sanitation from the western type of sanitation. He wanted to introduce this type of sanitation in India. According to Gandhi Ji "I learned 35 years ago in the west that lavatories must as clean as drawing rooms." He felt logically that cause of many of our diseases is the condition of our dirty toilets and open defecations anywhere. Mahatma Gandhi learned self scavenging during the South Africa trip. After returning back he offered his service for improving the sanitation of the city. Gandhi Ji suggested to the scavengers the use of two buckets for urine and night soil. Gandhi Ji was desperate to abolish untouchability and scavenging from India. He called them "The Harijans" i.e. the people of God and frequently went to their colonies for taking meals with them.

Gandhi Ji launched a mass contact plan in the villages to talk about broom and spades. He also spread awareness among the villagers regarding the need to keep their house clean instead of throwing the garbage here and there. Once he 
Relevance of Gandhian Thoughts about Sanitation and Related Policies of Government: ............... Dr. Anchal Gupta

visited the government servant quarters of Pune and emphasized that servant quarters should be as clean as the master's bungalow. So, we can say that Gandhiji spread the clear concept of sanitation before so many decades and it is relevant and meaningful even in the present era.

The mother of Dr. Bindeshwar Pathak (Founder of Sulabh International) gave the same advice to him as the mother of Gandhiji had done. Dr.Pathak not only saved the lives of millions of scavengers in India but also restored their human rights and dignity. He also generated the new concept of Public toilets (सुलभ शौचालय) in order to abolish the evil of scavenging. Along with the help of the government and the private sector he also implemented this concept for the rural individual households keeping in mind the importance of health and hygiene. Due to this revolutionary work, he was recently appointed as the brand ambassador of the "Swacch Bharat Rail Mission" by the ministry of Indian Railways on November 2, 2016.

\section{Government Policies related to Sanitation:}

The problem of health and sanitation has also gained high importance in modern times. A number of national and international agencies are working for improving health and sanitary conditions in the world. These agencies have realized the importance of good hygienic conditions for the quality development of the human population. The Government of India also has multiple sanitation policies across the country. The CENTRAL RURAL SANITATION program in 1986 was formulated, providing an $80 \%$ Subsidy for building the individual sanitary latrines for the Below Poverty Line people on-demand basis to promote the sanitation and demolish the scavenging. In 1999 the program was re-launched with a high subsidy to a low subsidy model.

In 2001 CRS PROGRAMME overhauled with the introduction of the total sanitation campaign. The program cost was shared among $60 \%$ central, $20 \%$ state Government, and $20 \%$ of beneficiary. Nirmal Gram Purskar was launched to recognize the achievements and efforts of Gram Panchayat towards full sanitation coverage. In 2007 it was renamed to NIRMAL BHARAT ABHIYAN to facilitate individual households and schools, a community-level sanitation. In 2008 the urban sanitation got attention at the national level. The National Urban Sanitation Policy started a framework for cities to prepare city cleaning strategies.

On Oct. $2^{\text {nd, }} 2014$ our honorable Prime Minister Mr. Narendra Modi launched a nationwide sanitation campaign SWACH BHARAT ABHIYAN on the occasion

of Mahatma Gandhi's birth anniversary. The concept of this campaign is to provide 
RJPSS Sept. 2020 Vol. XLV No.2, ISSN: (P)0258-1701 (e)2454-3403 Impact Factor: 7.717

https://doi.org/10.31995/rjpss.2020.v45i01.026

sanitation facilities to everyone which includes toilet, waste management, village cleanliness, and safe drinking supply, etc. We have to achieve this by 2019 as a tribute to Mahatma Gandhi on his $150^{\text {th }}$ birth anniversary. PM Modi says that this mission is beyond politics and inspired by patriotism.

\section{Conclusion:}

Thus, we can conclude that sanitation is important in our life as well as for the nation. It is well known that Mahatma Gandhi personally took the efforts to achieve the change that he wanted to observe. He also advised the students that "if you become your own scavenger you will make your surroundings clean". It is very necessary to spread awareness about health and sanitation for the sake of the nation. Public toilets should also be maintained properly. It can be done by either by private investment or by government grants. Education status of the society has to be improved. Increased awareness regarding various diseases and sanitation problems will lead to better hygienic practices. It is not only the responsibility of the government but also of all the citizens of the country.

An analysis of India's policies and programs towards sanitation has been purely programmatic. After so many financial efforts and billions of rupees have been sent in building toilets, even they are not being used in many places because of bad construction, poor quality, lack of water, and maintenance. So, there is an instant need for more awareness and civic efforts to make India clean. Indians also need a prompt and innovative thinking, applied behavior patterns, and choices to make the country open defecation free.

In the end, we can say that no policy, scheme, and program is not bad or ineffective by itself, the success of any government plan and policy lies in its functional purpose i.e. implementation. It is very essential to take initiative to achieve the goal of making India clean. Every Indian's active participation is required to fulfill the dream of the father of the nation Mahatma Gandhi.

\section{References:}

1. Content, Jeff (2005) Sanitation and Cleanliness for a healthy environment, Hesperian Foundation, USA

2. Duncan $M$ 'Appropriate Technology for water supply and sanitation Altimative for Low-income communities- A brief introduction, World Bank, Washington, 1952

3. Goode, W.J.Hatt, P.K 'Methods in social research

4. Hutton J.H. Census of India,1931, volume 1-India, Part 11-Imperial Tables, Manager of publications, Delhi, 1931 
Relevance of Gandhian Thoughts about Sanitation and Related Policies of Government: ............... Dr. Anchal Gupta

5. Kelman, S. 1975, the social nature of the definition problem in health', International Journal of health services,5:625-42

6. Lundburg, G 'Social Research Longmans, Green, and co., New York 1949

7. Malkani , N.R. 'Report of the scavenging conditions Inquiry Committee

8. Pathak B. 1991 Road to Freedom: A Sociological study on the Abolition of Scavengering in India, Delhi, Motilal Banarsidas publishers 